\title{
Use of Bacteriophages to Improve Food Safety
}

\author{
Murat Muhammet DÜLGER*, Haydar ÖZPINAR ${ }^{* *}$
}

\begin{abstract}
Food safety is a major concern for human health. Foodborne pathogens are responsible for several millions of cases annually worldwide. In order to inactivate these foodborne pathogens, numerous methods are available. However, these conventional methods have several drawbacks, such as heat treatment significantly affects nutritional properties of foods, chemical sanitizers leave residue on foods and food contact surfaces, high-pressure applications require special and relatively expensive equipment, and antibiotic use leads microorganisms to develop antibiotic resistance. One method that could overcome these drawbacks is bacteriophage application. Bacteriophages, or shortly phages, are viruses that infect bacteria, and they are found everywhere where bacteria are found. During the infection progeny phages are produced and phages inactivate bacteria by bursting the cell wall. Phage isolation can easily be done from natural sources like animal feces, wastewater, and sewage. In recent years, there have been many studies about phage application. When phages are applied on foods, they do not affect sensory or nutritional values of foods, humans, and environment. Also, since they are host specific, they only inactivate pathogenic bacteria. In addition, they have a different inactivation mechanism than antibiotics so phages can inactive antibiotic resistant bacteria as well. There are phage-based commercial products that are approved to be used on foods. On the other hand, there are technical and regulatory challenges. To overcome technical challenges, academic studies are being conducted. This study aims to generalize the use of bacteriophages in food industry by reviewing research articles in this area.
\end{abstract}

Keywords: Bacteriophage, phage, food safety, foodborne pathogens

\section{Bakteriyofajların Gıda Güvenliğini Artırmak Amacıyla Kullanılması}

\section{$\ddot{O} z$}

Gıda güvenliği insan sağlı̆̆ı ile önemli derecede ilgilidir. Gıda kaynaklı patojenler dünya çapında yılda milyonlarca vakaya sebep olmaktadırlar. Bu patojenleri inaktive etmek adına sayısız yöntem bulunmaktadır. Fakat bu alışılagelmiş metotların bazı dezavantajları bulunmaktadır. Örneğin ısıl işlemler gıdanın besleyici özelliklerine zarar verirler, kimyasal ilaçlar gıda üzerinde kalıntı bırakırlar, yüksek basınç gibi işlemler yüksek maliyetli cihaz gerektirirler ve antibiyotiklerin kullanımı sonucunda mikroorganizmalar hızla antibiyotik dirençliliği kazanmaktadırlar. Bakteriyofajlar bu sorunların üstesinden gelebilecek bir metot olarak görülmektedir. Bakteriyofajlar, ya da kısaca fajlar, doğada bakterinin bulunduğu her yerde bulunan, hedef mikroorganizmaya özgü ve sadece bakterileri enfekte eden virüslerdir. Enfeksiyon sonucu hücre içinde fajlar çoğalırlar ve bakterinin hücre duvarını patlatarak bakteriyi inaktive ederler. Doğada büyükbaş, küçükbaş ve kümes hayvanlarının dışkıları, atık sular ve kanalizasyonlar gibi bakterilerin yoğun bir şekilde bulunduğu yerlerden rahatça faj izolasyonu yapılabilmektedir. Son yllarda fajların gıda üzerinde kullanılması ile ilgili birçok çalışma yapılmıştır. Fajlar gıda üzerine uygulandıklarında gıdanın duyusal ve besleyici özelliklerine, insana, çevreye zarar vermezler ve hedef bakteriye özgü olduklarından yararlı mikroorganizmaları inaktive etmezler. Ayrıca inaktivasyon mekanizması antibiyotiklerden farklı

Derleme Makale (Review Article)

Geliş / Received: 05.10.2021 \& Kabul / Accepted: 24.12.2021

DOI: https://doi.org/10.38079/igusabder.1004988

${ }^{*}$ Res. Assist., Altınbaş University, Faculty of Applied Sciences, Department of Gastronomy and Culinary Arts, Istanbul,

Turkey, E-mail: murat.dulger@altinbas.edu.tr ORCID https://orcid.org/o00o-0001-6681-8049

${ }_{* *}^{*}$ Prof. Dr., Istanbul Aydın University, Faculty of Health Sciences, Nutrition and Dietetics Department, Istanbul, Turkey,

E-mail: haydarozpinar@aydin.edu.tr ORCID https://orcid.org/oooo-0003-3846-9907 
olduğundan antibiyotiğe dirençli bakterileri de etkili bir şekilde inaktive ederler. Kimyasal uygulama içermediğinden gıda üzerinde bir kimyasal kalıntı bırakmaz ve uygulanması sırasında pahalı ekipmanlara ihtiyaç duyulmaz. Ticarî olarak gıda üzerinde direkt kullanımı onaylanmış faj bazlı ürünler bulunmaktadır. Öte yandan bakteriyofajların gıda üzerinde kullanılmalarının teknik ve yasal zorlukları da bulunmaktadır. Teknik zorlukları aşmak amacıyla akademik çalışmalar devam etmektedir. Yasal olarak ise bakteriyofaj kullanımı ABD ve Avrupa Birliği’nde belli başlı ürünlerde onay almıştır. Bu çalışma, bu alanda yapılan özgün çalışmaları derleyerek bakteriyofaj kullanımının yaygınlaştırılmasını amaçlamaktadır.

Anahtar sözcükler: Bakteriyofaj, faj, gıda güvenliği, gıda kaynaklı patojenler

\section{Introduction}

According to Havelaar et al. World Health Organization (WHO) Foodborne Disease Burden Epidemiology Reference Group (FERG) estimated that in 2010, more than half of 600 million foodborne illnesses are caused by bacteria and among those bacteria the most common ones are Listeria monocytogenes, Campylobacter spp., Escherichia coli, Shigella spp. and non-typhoidal Salmonella enterica ${ }^{1}$. These bacteria also cause a massive burden on economy. In a study that was conducted in 2012, it was estimated that in USA, foodborne infections cause around $\$ 1,500$ per person and more than $\$ 75$ billion per year ${ }^{2}$.

There are various methods to improve food safety. One of the most used methods is thermal treatment. However, this method is not applicable for foods that are consumed raw or that are heat sensitive. Also, while decreasing the number of viable bacteria, heat treatment also damages the sensory properties or nutritional values of the food. Other non-thermal methods, such as high hydrostatic pressure, chemical disinfectants, or ionizing radiation, are effective in inactivating bacteria however they have other disadvantages. They are harmful for human health and environment, not accepted by consumers, and they damage sensory and nutritional properties of the food as well3. At this point, bacteriophages look like a promising antibacterial agent. Phages, since their discovery, have been used in the field of medicine to treat bacterial infections 4 . With the discovery and success of antibiotics, phages lost their popularity but increasing antibiotic use led bacteria to develop antibiotic resistance and recently phages regained their attention not only in the field of medicine but also in the food industry. Phage application does not affect sensory properties and nutritional values of the food while inactivating pathogenic bacteria because phages are host specific, meaning they inactivate only the target bacteria. Thanks to this property of phages, they do not affect humans and environment. There are several companies that produce phage-based food sanitizers. In USA Intralytix, Inc., in Netherlands Micreos Food Safety, in Germany FINK TEK GmbH produce phage-based products and these products are approved by governmental and international agencies such as Food and Drug Administration (FDA) and European Food Safety Authority (EFSA)3.

Bacteriophage application also has some disadvantages and challenges. One of the challenges is that phages are host specific. If the food that is to be treated with phages is contaminated with more than one type of bacteria a single type of phage will not be enough to eliminate all pathogens. In this situation a mixture of different types of phages will be needed. Another problem is that phages cannot be used together with other methods because other methods eliminate phages as well as bacteria. Therefore, when phage application is combined with another method, efficiency does not increase, maybe even decrease. One other challenge is that the type of the bacteriophage is also important. There are two types of bacteriophages: lytic and lysogenic. When lytic phages infect target bacteria, they take control over the protein synthesis mechanism of the host cell, produce progeny phages, and burst the host cell to infect other bacteria. However, lysogenic 
phages do not inactivate host cell during their life cycle. Lysogenic phages, when they infect a target bacterium, integrate their genetic material with the host cell's chromosome and continue their life cycle together with the host cell. The fact that target bacterium is not inactivated is not the main concern. Lysogenic phages, at some point, may enter lytic cycle so they burst the cell and infect other bacteria. In this situation, phages might carry antibiotic resistance or virulence genes to the new host cell5. Therefore, the phages that are to be used in bacteriophage application should strictly be lytic phages.

This paper is focused on studies that use bacteriophages on foods. In the field of food science, phages can be used pre-harvest, before slaughter of livestock, or applied directly on food surfaces. In this study, academic studies that focused on these types of bacteriophage usage are reviewed.

\section{Phage Application Against Common Foodborne Pathogens}

\section{Listeria Monocytogenes}

Listeria monocytogenes are Gram-negative bacteria with a mortality rate of $20-30 \%$. The symptoms include fever, muscle ache, severe headache, nausea, vomiting, stiff neck, loss of balance and convulsion6. L. monocytogenes are psychrophiles, meaning that they can grow at temperatures as low as $4^{\circ} \mathrm{C}$. Therefore, they are prevalent in ready-to-eat foods and foods that are consumed raw, so it is particularly important to develop a phage application targeting these bacteria. According to a study conducted in 2015, a phage solution named ListShield ${ }^{\mathrm{TM}}$ was applied on artificially contaminated cheese, apple, and lettuce. The number of bacteria dropped by up to 1.1-log. In addition, the phage solution was able to drop the number of bacteria to undetectable levels on foods that are frozen after the phage application7. This and other studies were briefly summarized in Table 1.

\section{Salmonella Spp.}

Salmonella are Gram-negative bacteria that can cause cramps, fever, nausea, and diarrhea. Combined with dehydration, it may lead to death 3 . According to FERG, in 2010 around 78 million Salmonella cases were reported and more than 60 thousand of those were resulted in death of the patient ${ }^{1}$. Salmonella generally transmits to humans through chicken, turkey, eggs, and beef ${ }^{8}$. Therefore, phages targeting Salmonella can easily be isolated from animal sources. In a study conducted in 2018, 58 different phages were isolated from a poultry house, a wastewater treatment plant, a farm ditch, and a sewage near a river. Among all, phages named LPST10 and LPST18 were found to be very effective against Salmonella Typhimurium?.

\section{Escherichia Coli}

Most strains of Escherichia coli are harmless but others can cause severe gastrointestinal diseases ${ }^{10}$. Pathogenic strains of $E$. coli transmits to humans through raw or undercooked beef, raw milk, animal feces, water contaminated with animal feces, or vegetables irrigated with contaminated water ${ }^{11}$. According to a study in 2016, E. coli is the most common extended spectrum beta-lactamase (ESBL) positive (antibiotic resistant) bacteria in chicken meat, raw cow milk and raw cow milk cheese in Turkey ${ }^{12}$. Therefore, it is especially important to develop phage applications targeting pathogenic E. coli. When studies about phages targeting E. coli are looked over, it can be seen that successful results are obtained on green leafy vegetables and in milk ${ }^{13^{-15}}$. In a study, a commercial phage product named EcoShield ${ }^{\mathrm{TM}}$ is used against $E$. coli on lettuce. Two different applications were analyzed, first phages were sprayed on lettuce and secondly lettuce leaves were immersed in phage solution. After both applications samples were stored in $4^{\circ} \mathrm{C}$ for seven days and bacteria number dropped to undetectable limits after fourth day ${ }^{13}$. 


\section{Shigella Spp.}

Shigella are Gram-negative bacteria and generally transmitted through water contaminated with feces in developing countries. As low as 10-200 cells can cause shigellosis ${ }^{16}$. According to FERG, more than 15,000 cases resulted in death of 50 million total cases in $2010^{1}$. In a study conducted in 2019, two phages named vB_SflS-ISFoo1 and vB_SsoS-ISFoo2 were tested against Shigella spp. separately and together, and up to $2.7-\log$ reduction was observed ${ }^{17}$.

\section{Campylobacter Jejuni}

Campylobacter species are one of the most common pathogenic foodborne bacteria. According to FERG, the number of cases went over 95 million and 21,000 of those cases resulted in death ${ }^{1}$. One of the most common sources of Campylobacter infections is eating raw or undercooked poultry ${ }^{18}$. Phages targeting Campylobacter species can also be isolated from poultry samples. According to a study, two phages obtained from poultry samples applied in two doses separately reduced the number of Campylobacter in the feces of poultry by $3-\log 19$.

Table 1. Summary of studies of phage applications targeting common foodborne pathogens

\begin{tabular}{|c|c|c|c|c|}
\hline $\begin{array}{l}\text { Target } \\
\text { bacteria }\end{array}$ & Bacteriophages & $\begin{array}{l}\text { The Food } \\
\text { Bacteriophages } \\
\text { Applied }\end{array}$ & Effect & Reference \\
\hline $\begin{array}{l}\text { Listeria } \\
\text { monocytogenes }\end{array}$ & $\begin{array}{l}\text { PhageGuard } \\
\operatorname{Listex}^{\text {TM }}(\mathrm{P} 100)\end{array}$ & Sliced pork ham & $\begin{array}{l}\text { After } 72 \text { hours number of bacteria } \\
\text { was reduced to undetectable levels } \\
\text { from an initial load of around 4-log. }\end{array}$ & 20 \\
\hline $\begin{array}{l}\text { Listeria } \\
\text { monocytogenes }\end{array}$ & ListShield $^{\mathrm{TM}}$ & Cheese, apple, lettuce & $\begin{array}{l}\text { 1.1-log reduction was achieved from } \\
\text { initial loads of around } 3 \cdot 5 \text {-log, when } \\
\text { samples were frozen after the phage } \\
\text { application bacterial number was } \\
\text { reduced to undetectable levels. }\end{array}$ & 7 \\
\hline $\begin{array}{l}\text { Listeria } \\
\text { monocytogenes }\end{array}$ & $\begin{array}{l}\text { PhageGuard } \\
\operatorname{Listex}^{\text {TM }}(\mathrm{P} 100)\end{array}$ & Cheese & $\begin{array}{l}\text { 3-log reduction was observed in } 30 \\
\text { minutes. Regrowth was observed } \\
\text { when samples were stored at } 10^{\circ} \mathrm{C}\end{array}$ & 21 \\
\hline $\begin{array}{l}\text { Salmonella } \\
\text { spp. }\end{array}$ & SJ2 & Beef, eggs & $\begin{array}{l}\text { Up to } 1.5 \text {-log reduction was observed } \\
\text { and reduction was better at room } \\
\text { temperature. }\end{array}$ & 22 \\
\hline $\begin{array}{l}\text { Salmonella } \\
\text { spp. }\end{array}$ & PhageGuard $\mathrm{S}^{\mathrm{TM}}$ & Ground beef & $\begin{array}{l}\text { Using phage application and } \\
\text { irradiation on the same sample } \\
\text { separately, they both reduce the } \\
\text { bacterial number by } 1 \text {-log and total } \\
\text { reduction is } 2-\log \text {. }\end{array}$ & 23 \\
\hline $\begin{array}{l}\text { Salmonella } \\
\text { spp. }\end{array}$ & LPST153 & $\begin{array}{l}\text { Pasteurized milk, raw } \\
\text { sausage }\end{array}$ & $\begin{array}{l}3 \cdot 3-\log \text { reduction was observed at } \\
25^{\circ} \mathrm{C} \text { after } 12 \text { hours. }\end{array}$ & 24 \\
\hline $\begin{array}{l}\text { Escherichia } \\
\text { coli }\end{array}$ & FAHEc1 & Milk and beef & $\begin{array}{l}\text { Phages were treated with mild UV } \\
\text { light before they were applied on } \\
\text { food sample, in order to prevent } \\
\text { unwanted gene transfer. Phages were } \\
\text { still able to inactivate bacteria } \\
\text { effectively. }\end{array}$ & 14 \\
\hline $\begin{array}{l}\text { Escherichia } \\
\text { coli }\end{array}$ & OSY-SP & $\begin{array}{l}\text { Sliced green pepper } \\
\text { and spinach leaves }\end{array}$ & $\begin{array}{l}\text { Up to 4-log reduction was observed. } \\
\text { Regrowth was seen on samples } \\
\text { stored at } 25^{\circ} \mathrm{C} \text {. }\end{array}$ & 15 \\
\hline $\begin{array}{l}\text { Escherichia } \\
\text { coli }\end{array}$ & JNo2 & Milk, beef surface & $\begin{array}{l}\text { Number of bacteria dropped below } \\
\text { detectable levels after } 24 \text { hours from } \\
\text { an initial load of } 10^{4} \mathrm{CFU} / \mathrm{ml} \text {. }\end{array}$ & 25 \\
\hline $\begin{array}{l}\text { Escherichia } \\
\text { coli }\end{array}$ & $\begin{array}{l}20 \text { different } \\
\text { phages isolated } \\
\text { from farm }\end{array}$ & Cucumber & $\begin{array}{l}\text { After } 24 \text { hours at } 4^{\circ} \mathrm{C} \text { bacteria } \\
\text { number was dropped to } 1.6-\log \\
\mathrm{CFU} / \mathrm{g} \text { from } 3 \text {-log } \mathrm{CFU} / \mathrm{g} .\end{array}$ & 26 \\
\hline
\end{tabular}




\begin{tabular}{|c|c|c|c|c|}
\hline & samples & & & \\
\hline $\begin{array}{l}\text { Escherichia } \\
\text { coli }\end{array}$ & $\begin{array}{l}\text { EcoShield }^{\mathrm{TM}} \\
\text { (USA, Intralytix) }\end{array}$ & Lettuce & $\begin{array}{l}\text { Samples were stored at } 4^{\circ} \mathrm{C} \text { for seven } \\
\text { days and after fourth day, the } \\
\text { number of bacteria dropped below } \\
\text { detectable limits from initial loads of } \\
\text { around } 2.5 \text { - } \log \mathrm{CFU} / \mathrm{cm}^{2} \text {. }\end{array}$ & 13 \\
\hline Shigella sonnei & ShigaShield $^{\mathrm{TM}}$ & $\begin{array}{l}\text { Ready to eat foods, } \\
\text { lettuce, melon, } \\
\text { smoked salmon, } \\
\text { corned beef, chicken } \\
\text { breast }\end{array}$ & $\begin{array}{l}\text { Up to } 1.4-\log \text { reduction was } \\
\text { observed. }\end{array}$ & 27 \\
\hline Shigella spp. & $\begin{array}{l}\text { vB_SflS-ISFoo1 } \\
\text { vB_SsoS-ISFoo2 }\end{array}$ & Beef & $\begin{array}{l}\text { Two phages were applied separately. } \\
2.8 \text { and 3.1-log reductions were } \\
\text { observed. When used together, 3.9- } \\
\text { log reduction was achieved. }\end{array}$ & 17 \\
\hline $\begin{array}{l}\text { Shigella } \\
\text { flexneri }\end{array}$ & vB_SflS-ISFoo1 & $\begin{array}{l}\text { Raw and cooked } \\
\text { chicken breast }\end{array}$ & $\begin{array}{l}\text { Around 2-log reduction was } \\
\text { observed. Reduction on cooked } \\
\text { samples were slightly higher. }\end{array}$ & 28 \\
\hline $\begin{array}{l}\text { Campylobacter } \\
\text { jejuni }\end{array}$ & $\begin{array}{l}\text { Ф7-izsam } \\
\Phi 16 \text {-izsam }\end{array}$ & Poultry animals & $\begin{array}{l}\text { Two phages were given to poultry } \\
\text { animals prior to slaughter and } \\
\text { phages were able to achieve } 2-\log \\
\text { reduction. }\end{array}$ & 29 \\
\hline $\begin{array}{l}\text { Campylobacter } \\
\text { jejuni } \\
\text { Campylobacter } \\
\text { coli }\end{array}$ & $\begin{array}{l}\text { PH1-PH19 } \\
\text { (19 different } \\
\text { phages) }\end{array}$ & Poultry animals & $\begin{array}{l}\text { Phages were mixed to animal feed } \\
\text { prior to slaughter in three farms. } \\
\text { While phages were able to achieve up } \\
\text { to } 3 \text {-log reduction at one farm, at } \\
\text { other farms they were ineffective. }\end{array}$ & 30 \\
\hline $\begin{array}{l}\text { Campylobacter } \\
\text { jejuni } \\
\text { Campylobacter } \\
\text { coli }\end{array}$ & $\begin{array}{l}\text { Two different } \\
\text { phage cocktails } \\
\text { composed of } 6 \\
\text { and } 5 \text { different } \\
\text { phages }\end{array}$ & Poultry animals & $\begin{array}{l}\text { Phages were given to poultry as two } \\
\text { cocktails that were used together and } \\
\text { up to } 3 \text {-log reduction was observed. } \\
\text { However, when phages were applied } \\
\text { separately no significant reduction } \\
\text { was observed. }\end{array}$ & 19 \\
\hline
\end{tabular}

\section{Limitations and Challenges of Bacteriophage Applications}

Despite their success in biocontrol of foodborne pathogens, phage applications have several limitations and challenges. One of the challenges is that phages might cause unwanted genetic material transfer. When bacteriophages infect target cell, they take over the protein synthesis mechanism of the cell and start to produce progeny phages. During this cycle, it is highly possible to take antibiotic resistance or virulence genes from the bacteria and transfer it to other bacteria during another cycle ${ }^{14}$. One of the solutions of this problem is using lytic phages. Since lytic phages inactivate bacteria at the end of their life cycle, these genetic material transfer will not be important. Another solution proposed by Hudson et al. is exposing phages to UV light to decrease their reproduction ability. By doing so chances of unwanted genetic material transfer are also decreased. However, UV light also decreases phages' ability to inactivate bacteria so deciding the dose of UV light is crucial.

Another challenge is regulatory challenges. Authorities like FDA and EFSA approved several commercial bacteriophage products to be used by direct contact to food surfaces. EcoShield ${ }^{\mathrm{TM}}$ produced by Intralytix, Secure Shield E1 produced by FINK TEC GmbH and PhageGuard E produced by Micreos Food Safety are classified as GRAS (generally recognized as safe) ${ }^{31}$.

Application of bacteriophages also have some technical challenges. Especially on solid food samples only surface sanitation is achieved as phages cannot diffuse through the food. Therefore, 
it can only be used effectively on food samples where surface sanitation is enough such as spinach or lettuce. In liquid foods, phages are generally more effective as they can move passively in the liquid medium ${ }^{3}$. Another challenge is the fact that regrowth is seen after the initial reduction ${ }^{15,32}$. When the studies where regrowth was seen are analyzed it was seen that regrowth is generally seen when samples are stored at room temperature. Therefore, the solution of this problem is to keep foods in cold chain after the phage application, but this also increases cost.

Finally, bacteriophages are not accepted by consumers. Even though they are host specific, environmentally friendly, non-chemical, and not harmful to humans, "adding viruses to foods" is not an attractive idea. For this reason, food producers must inform the public to be accepted by consumers.

\section{Conclusion}

Despite having some challenges, bacteriophage application seems to be a promising method to increase food safety. Commercial phage products are continuing to get approvals from international authorities and becoming more popular. In food industry, phages can be used preharvest, prior to slaughter or during food processing. While decreasing the viability of bacteria, bacteriophages do not affect sensory properties and nutritional values of the foods, human health, and environment. Academic studies are being conducted to improve bacteriophage applications. In the industry, commercially available phage-based products are available.

\section{REFERENCES}

1. Havelaar AH, Kirk MD, Torgerson PR, et al. World Health Organization Global Estimates and Regional Comparisons of the Burden of Foodborne Disease in 2010. PLoS Medicine. 2015;12(12):e1001923. doi:10.1371/journal.pmed.1001923.

2. Scharff RL. Economic Burden from Health Losses Due to Foodborne Illness in the United States. Journal of Food Protection. 2012;75(1):123-131. doi:10.4315/0362-028X.JFP-11058.

3. Moye ZD, Woolston J, Sulakvelidze A. Bacteriophage Applications for Food Production and Processing. Viruses. 2018;10(4). doi:10.3390/v10040205.

4. López-Cuevas O, Medrano-Félix JA, Castro-Del Campo N, Chaidez C. Bacteriophage applications for fresh produce food safety. International Journal of Environmental Health Research. 2021;31(6):687-702. doi:10.1080/09603123.2019.1680819.

5. Hudson JA, Bigwood T, Premaratne A, Billington C, Horn B, McIntyre L. Potential to use ultraviolet-treated bacteriophages to control foodborne pathogens. Foodborne Pathogens and Disease. 2010;7(6):687-693. doi:10.1089/fpd.2009.0453.

6. Food and Drug Administration. Get the Facts about Listeria. https://www.fda.gov/animalveterinary/animal-health-literacy/get-facts-about-listeria. Published Date 2020. Accessed Date October 32021.

7. Perera MN, Abuladze T, Li M, Woolston J, Sulakvelidze A. Bacteriophage cocktail significantly reduces or eliminates Listeria monocytogenes contamination on lettuce, apples, cheese, smoked salmon and frozen foods. Food Microbiology. 2015;52:42-48. doi:10.1016/j.fm.2015.06.006.

8. Centers for Disease Control and Prevention. Salmonella and Food. 
https://www.cdc.gov/foodsafety/communication/salmonella-food.html. Published Date 2021.

9. Huang C, Shi J, Ma W, et al. Isolation, characterization, and application of a novel specific Salmonella bacteriophage in different food matrices. Food Research International. 2018;111:631-641. doi:https://doi.org/10.1016/j.foodres.2018.05.071.

10. Centers for Disease Control and Prevention. Questions and Answers. https://www.cdc.gov/ecoli/general/index.html. Published Date 2014. Accessed Date October 3, 2021.

11. World Health Organization. E. coli. https://www.who.int/news-room/fact-sheets/detail/ecoli. Published Date 2018. Accessed Date October 3, 2021.

12. Tekiner İH, Özpınar H. Occurrence and characteristics of extended spectrum betalactamases-producing Enterobacteriaceae from foods of animal origin. Brazilian Journal of Microbiology. 2016;47(2):444-451. doi:https://doi.org/10.1016/j.bjm.2015.11.034.

13. Ferguson S, Roberts C, Handy E, Sharma M. Lytic bacteriophages reduce Escherichia coli O157. Bacteriophage. 2013;3(1):e24323. doi:10.4161/bact.24323.

14. Hudson JA, Billington C, Premaratne A, On SLW. Inactivation of Escherichia coli O157:H7 using ultraviolet light-treated bacteriophages. Food Science and Technology International. 2016;22(1):3-9. doi:10.1177/1082013214560445.

15. Snyder AB, Perry JJ, Yousef AE. Developing and optimizing bacteriophage treatment to control enterohemorrhagic Escherichia coli on fresh produce. International Journal of Food Microbiology. 2016;236:90-97. doi:10.1016/j.ijfoodmicro.2016.07.023.

16. Aslam A, Okafor CN. Shigella. In: StatPearls; 2021.

17. Shahin K, Bouzari M, Wang R, Yazdi M. Prevalence and molecular characterization of multidrug-resistant Shigella species of food origins and their inactivation by specific lytic bacteriophages. International Journal of Food Microbiology. 2019;305:108252. doi:https://doi.org/10.1016/j.ijfoodmicro.2019.108252.

18. Centers for Disease Control and Prevention. Campylobacter (Campylobacteriosis). https://www.cdc.gov/campylobacter/index.html. Published Date December 23, 2019.

19. Hammerl JA, Jäckel C, Alter T, et al. Reduction of campylobacter jejuni in broiler chicken by successive application of group II and group III phages. PloS One. 2014;9(12):e114785e114785. doi:10.1371/journal.pone.0114785.

20. Figueiredo ACL, Almeida RCC. Antibacterial efficacy of nisin, bacteriophage P1oo and sodium lactate against Listeria monocytogenes in ready-to-eat sliced pork ham. Brazilian Journal of Microbiology . 2017;48(4):724-729. doi:10.1016/j.bjm.2017.02.010.

21. Silva ENG, Figueiredo ACL, Miranda FA, de Castro Almeida RC. Control of Listeria monocytogenes growth in soft cheeses by bacteriophage P10o. Brazilian Journal of Microbiology. 2014;45(1):11-16. doi:10.1590/s1517-83822014000100003

22. Hong Y, Schmidt K, Marks D, et al. Treatment of Salmonella-contaminated eggs and pork with a broad-spectrum, single bacteriophage: assessment of efficacy and resistance development. Foodborne Pathogens and Disease. 2016;13(12):679-688. doi:10.1089/fpd.2016.2172. 
23. Yeh Y, de Moura FH, Van Den Broek K, de Mello AS. Effect of ultraviolet light, organic acids, and bacteriophage on Salmonella populations in ground beef. Meat science. 2018;139:44-48. doi:10.1016/j.meatsci.2018.01.007.

24. Islam MS, Hu Y, Mizan MFR, et al. Characterization of salmonella phage LPST153 that effectively targets most prevalent salmonella serovars. Microorganisms. 2020;8(7). doi:10.3390/microorganisms8071089.

25. Li YK, Wu X, Chen H, et al. A bacteriophage JNo2 infecting multidrug-resistant Shiga toxin-producing Escherichia coli: isolation, characterisation and application as a biocontrol agent in foods. International Journal of Food Science |\& Technology. 2021;n/a(n/a). doi:https://doi.org/10.1111/ijfs.15070.

26. Mangieri N, Picozzi C, Cocuzzi R, Foschino R. Evaluation of a potential bacteriophage cocktail for the control of shiga-toxin producing Escherichia coli in food. Frontiers in Microbiology. 2020;11:1801. doi:10.3389/fmicb.2020.01801.

27. Soffer N, Woolston J, Li M, Das C, Sulakvelidze A. Bacteriophage preparation lytic for Shigella significantly reduces Shigella sonnei contamination in various foods. PloS One. 2017;12(3):e0175256-e0175256. doi:10.1371/journal.pone.0175256.

28. Shahin K, Bouzari M. Bacteriophage application for biocontrolling Shigella flexneri in contaminated foods. Journal of Food Science and Technology. 2018;55(2):550-559. doi:10.1007/s13197-017-2964-2.

29. D'Angelantonio D, Scattolini S, Boni A, et al. Bacteriophage therapy to reduce colonization of campylobacter jejuni in broiler chickens before slaughter. Viruses. 2021;13(8). doi:10.3390/v13081428.

30. Chinivasagam HN, Estella W, Maddock L, et al. Bacteriophages to control campylobacter in commercially farmed broiler chickens, in Australia. Frontiers in Microbiology. 2020;11:632. doi:10.3389/fmicb.2020.00632.

31. Pinto G, Almeida C, Azeredo J. Bacteriophages to control Shiga toxin-producing E. coli safety and regulatory challenges. Critical Reviews in Biotechnology. 2020;40(8):10811097. doi:10.1080/07388551.2020.1805719.

32. Duc HM, Son HM, Yi HPS, et al. Isolation, characterization and application of a polyvalent phage capable of controlling Salmonella and Escherichia coli $\mathrm{O}_{157}: \mathrm{H}_{7}$ in different food matrices. Food Research International. 2020;131:108977.

doi:https://doi.org/10.1016/j.foodres.2020.108977. 